\title{
Identification and clinical significance of Klebsiella species in chest infections
}

\author{
J. H. DARRELL AND A. D. F. HURDLE 1 \\ From the Postgraduate Medical School of London
}

SYNOPSIS Using a short series of biochemical tests already in use in many routine laboratories, it is possible to identify strains of the genus Klebsiella and to differentiate $K$. aerogenes from other types. Marked production of slime is not peculiar to the group and colonial appearance alone is not a satisfactory basis for identification. $K$. aerogenes is the type most commonly isolated from all clinical specimens. It is suggested that the name may be retained in clinical bacteriology and used when applicable, particularly when reporting urinary strains. $K$. aerogenes is of doubtful pathogenicity when isolated from sputum; frequently its appearance follows antibiotic treatment for other organisms. It should be clearly distinguished from other Klebsiella types occurring as primary pathogens in sputum. Friedlander's bacillus is considered a suitable collective term for the latter, namely $K$. edwardsii-edwardsii, $K$. pneumoniae, and $K$. edwardsii-atlantae. The clinical significance of $K$. rhinoscleromatis and $K$. ozaenae could not be assessed as so few isolations were made. On the rare occasions when they occur they would, with the tests recommended, be included as Friedlander's bacillus, the distinction not being readily made in the clinical laboratory.

With the increasing incidence of Gram-negative bacilli as a cause of hospital infections (Yow, 1952; Finland, Jones, and Barnes, 1949; Williams, Williams, and Hyams, 1960; Barber, 1961) it is important to distinguish likely pathogens from organisms whose presence is largely incidental. Klebsiella species are among those occurring more often. The identification and nomenclature of this group remains a matter of conflicting opinion, with resulting confusion as to their significance. With the rejection of the generic term 'Bacterium' (Report, 1954) many workers followed American practice (see Breed, 1948) in classifying B. lactis aerogenes as Aerobacter, and Friedlander's bacillus as Klebsiella. Kauffmann $(1949,1954)$ and other workers maintained that non-motile Aerobacter strains could not be differentiated from Klebsiella species, and the Enterobacteriacae Subcommittee, accepting this proposition (Hormaeche and Edwards, 1958), recommended that these types also, irrespective of site of origin, be designated $K$. pneumoniae. This was confusing in clinical bacteriology since these organisms occur most commonly in urine specimens.

Cowan (1956) suggested a subgroup or species $K$. aerogenes, in the Klebsiella group, 'for organisms isolated by water bacteriologists', to avoid reporting a human pathogen. With other workers (Cowan,

${ }^{1}$ Present address: Department of Pathology, St. Thomas's Hospital Medical School, London, S.E.1.

Received for publication 14 February 1964.
Steel, Shaw, and Duguid, 1960) he showed that this type could be distinguished biochemically from other Klebsiella species. Foster and Bragg (1962) successfully applied Cowan's classification to strains from sputum.

Our routine clinical records showed that while Klebsiella species were occurring more frequently, particularly in sputa, their exact significance was often in doubt. In addition confusion was arising from reporting all Klebsiella strains under a single title, and it seemed necessary to distinguish $K$. aerogenes in clinical bacteriology also. We therefore applied Cowan's classification to strains from clinical material to establish whether $K$. aerogenes could be simply and rapidly distinguished, the relative frequency of its occurrence, and whether its presence had any different significance from that of other types. We also tried to discover an acceptable formula for reporting other Klebsiella types, in order to provide a meaningful clinical report, while avoiding the misuse of valid official terminology.

\section{MATERIAL AND METHODS}

The investigation extended over one year during which Klebsiella species isolated from routine specimens in the clinical laboratory were tested. Gram-negative rods fermenting adonitol or inositol in 48 hours were accepted as possible Klebsiella strains (Talbot, Cunliffe, and Gower, 1957; Foster and Bragg, 1962). Predominant growths of coliforms from all types of specimen were 
tested for these properties. After six months 60 strains had been isolated and the distribution of types in specimens from various sites was established. The investigation was then limited to sputa, and strains were collected from several hospitals.

Sputum specimens were initially homogenized using glass beads and sterile saline. The method was unsatisfactory for very viscid specimens and had no apparent advantage over the careful selection of a purulent portion from the specimen spread in a Petri dish, which is our present routine method. A Gram film was prepared and the sputum plated on blood agar and incubated in air overnight. Clinical details were recorded as specimens were received, particular attention being paid to whether the organism was isolated from the first specimen examined or whether a previous pathogen had been present and if so whether antibiotic treatment had been given. $X$-ray appearances were not recorded.

BIOCHEMICAL TESTS Gas production from glucose, fermentation of lactose and dulcitol, gluconate oxidation, and ability to grow in $\mathrm{KCN}$ were tested by the accepted methods used and described by Foster and Bragg (1962). Additional tests or modifications of further tests used by them were also used and are listed below.

Motility A simple wet preparation, ringed with vaseline, from a four-hour peptone water culture incubated at $37^{\circ} \mathrm{C}$. was made.

$\mathrm{H}_{2} \mathrm{~S}$ production Lead acetate papers were inserted over the peptone water culture.

Malonate utilization The method of Shaw and Clarke (1955) was used.

Cellobiose fermentation A $1 \%$ solution in peptone water as for other fermentation tests was used.

Citrate Koser's citrate was used, a second tube being inoculated when the first was positive. All strains were tested in parallel using Simmon's (Oxoid) agar and no discrepancies occurred.

Urea A fluid version of Christensen's medium was used (Maslen, 1952).

Methyl red and Voges-Proskauer reactions Organisms are grown in buffered glucose broth for $30 \mathrm{hr}$. at $37^{\circ} \mathrm{C}$. and tested by Barritt's method.
ANTIBIOTIC SENSITIVITY TESTS Sensitivity to antibiotics was tested on ditch plates. The concentration of anti- $\vec{F}$ biotics (in $\mu \mathrm{g} . / \mathrm{ml}$.) was as follows:-Penicillin $6, \overline{0}$ ampicillin 50, streptomycin 20 , tetracycline 25 , chloramphenicol 50, polymyxin 200, kanamycin 200 . Zones of $\overline{\bar{\omega}}$ inhibition were compared with those of a standard $\frac{\vec{D}}{D}$ sensitive strain of Escherichia coli. For sulphonamide $\unrhd$ sensitivity tests lysed blood agar containing $100 \mathrm{mg} . / 100$ ڤ్ ml. sulphathiazole was used.

MOUSE PATHOGENICITY TEST All strains from sputum were tested using a $10^{5}$ dilution of an overnight peptone $\vec{\omega}$ water culture (Stokes, 1960), and by a modification of the method used by Foster and Bragg, an overnight broth culture was added drop-wise to a measured volume of $\vec{V}$ saline until turbidity was just detectable with the naked or eye. In each case $0.1 \mathrm{ml}$. was injected intraperitoneally $\dot{ }$ and the test considered positive if the mouse died within $\vec{\nabla}$ 72 hours and the organism was isolated from the heart $\mathrm{O}$ blood.

\section{RESULTS}

The diagnostic scheme of Cowan et al. is reproduced in Table I. In our survey the various types occurred in similar proportions in clinical specimens from different sites, as shown in Table II, giving the $\overrightarrow{\mathscr{C}}$

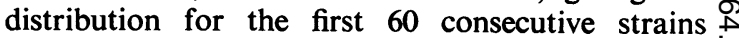
isolated. $K$. aerogenes occurred much more commonly than other types in all specimens. The biochemical reactions of our 47 Klebsiella strains from sputum are shown in Table III. $K$. aerogenes is readily distinguished from other species on the results of the methyl red and Voges-Proskauer tests. In the routine laboratory all necessary information can be obtained using the IMViC (indole, methyl red, Voges-Proskauer, citrate) reactions and routine fermentation tests; other more complex tests add relatively little further information.

In sputum the appearance of $K$. aerogenes frequently followed antibiotic treatment; this was less often the case with other types of Klebsiella $\delta$

TABLE I

DIAGNOSTIC SCHEME OF COWAN et al. (1960)

\begin{tabular}{|c|c|c|c|c|c|}
\hline K. aerogenes & $\begin{array}{l}\text { K. edwardsii- } \\
\text { edwardsii }\end{array}$ & K. pneumoniae & $\begin{array}{l}\text { K. edwardsii- } \\
\text { atlantae }\end{array}$ & $\begin{array}{l}\text { K. rhino- } \\
\text { scleromatis }\end{array}$ & K. ozaena? \\
\hline
\end{tabular}

Fimbriae
Gas from glucose
Lactose (acid)1
Methyl red
Voges-Proskauer $^{1}$
Citrate $^{1}$
Urease $^{1}$
Gluconate $^{1}$
Malonate
Lysine decarboxylase $^{1}$
$44^{\circ}$ test
Dulcitol (acid)
KCN

$\begin{array}{cc}+ & - \\ + & - \\ + & (+) \\ - & \mathbf{d} \\ + & + \\ + & \mathbf{d} \\ + & + \\ + & + \\ + & \mathbf{d} \\ + & + \\ \mathbf{d} & - \\ \mathbf{d} & + \\ + & (+)=\text { delayed }\end{array}$

${ }^{1}$ Only characters thus marked were tested by us.

$\begin{array}{cc}+ & - \\ + & + \\ + & + \\ + & + \\ + & d \\ + & + \\ + & + \\ \mathbf{d} & - \\ + & + \\ + & - \\ + & +\end{array}$

-
-
+
-
-
-
+
-
+
+

-
+
+
+
$\bar{d}$
$\mathrm{~d}$
-
-
-
-


TABLE II

DISTRIBUTION OF KLEBSIELLA SPECIES IN VARIOUS TYPES OF CLINICAL SPECIMENS

\begin{tabular}{|c|c|c|c|c|c|}
\hline Type of Specimen & K. aerogenes & $\begin{array}{l}\text { K. edwardsii } \\
(2 \text { subtypes) }\end{array}$ & $K$. pneumoniae & $\begin{array}{l}K . \text { rhinoscleromatis } \\
\text { and } K \text {. ozaenae }\end{array}$ & Totals \\
\hline $\begin{array}{l}\text { Sputum } \\
\text { Throat swabs } \\
\text { Urine } \\
\text { Faeces } \\
\text { Pus }\end{array}$ & $\begin{array}{r}10 \\
2 \\
22 \\
12 \\
6\end{array}$ & $\begin{array}{l}4 \\
1 \\
1 \\
1 \\
-\end{array}$ & $\frac{1}{-}$ & $\begin{array}{ll}- & \\
- & \\
- & \\
& \text { Tota }\end{array}$ & $\begin{array}{r}14 \\
3 \\
23 \\
13 \\
7 \\
60\end{array}$ \\
\hline
\end{tabular}

TABLE III

BIOCHEMICAL REACTIONS OF KLEBSIELLA STRAINS ISOLATED FROM SPUTUM

No. of
Strains $\underset{\substack{\text { from } \\ \text { Glucose }}}{\begin{array}{c}\text { Lactose } \\ \text { (acid) }\end{array}} \begin{gathered}\text { Dulcite } \\ \text { (acid) }\end{gathered}$

\begin{tabular}{|c|c|c|c|c|c|c|c|c|c|c|c|c|c|c|}
\hline K. aerogenes & 35 & 35 & 33 & 9 & 20 & 34 & 35 & 35 & 35 & $5^{1}$ & 1 & 0 & 35 & 35 \\
\hline K. edwardsii-ed. & 5 & 5 & 4 & $\mathbf{0}$ & 1 & 5 & 4 & 5 & 5 & 0 & 0 & 5 & 4 & 5 \\
\hline K. edwardsii-atl. & 2 & 2 & 2 & 0 & 1 & 0 & 0 & 2 & 2 & 0 & $\mathbf{0}$ & 2 & 1 & 2 \\
\hline K. pneumoniae & 2 & 1 & 2 & 2 & 1 & 0 & 1 & $\mathbf{0}$ & 2 & 0 & 0 & 2 & 0 & 2 \\
\hline K. rhinoscleromatis & 2 & $\mathbf{0}$ & $\mathbf{0}$ & $\mathbf{0}$ & 0 & 0 & 0 & 2 & 2 & $\mathbf{0}$ & $\mathbf{0}$ & 2 & 0 & $\mathbf{0}$ \\
\hline K. ozaenae & 1 & 1 & (1) & $\mathbf{0}$ & $\mathbf{0}$ & 0 & 0 & 1 & 1 & 0 & 0 & 1 & 0 & 1 \\
\hline
\end{tabular}

These strains are now probably better designated Enterobacter aerogenes.

TABLE IV

RELATION BETWEEN KLEBSIELLA SPECIES ISOLATED FROM SPUTUM TO PREVIOUS ANTIBIOTIC THERAPY

Species Isolated

K. aerogenes (including Enterobacter aerogenes)

$K$. pneumoniae (including $K$. edwardsii species)

Other Klebsiella spp. (rhinoscleromatis and ozaenae)

Patients Receiving Previous

Antibiotic Treatment

Patients without Previous

Total

Antibiotics

$32^{1}(92 \%)$
$2(22 \%)$
1

$3(8 \%)$

$7(78 \%)$

2

35
9
3

${ }^{1}$ Ten patients had received ampicillin either alone or in combination with another antibiotic.

(Table IV). The antibiotic most commonly used before the appearance of Klebsiella was ampicillin, to which a high proportion of our strains, particularly $K$. aerogenes, was resistant (Table VI). Ampicillin was given in most cases for the treatment of Haemophilus influenzae in bronchitic patients. However, its use was not inevitably followed by secondary colonization by coliforms, and treatment with other antibiotics for other pathogens was also sometimes followed by the appearance of $K$. aerogenes (Table V).

During the period of the investigation 2,750 routine specimens of sputum were examined.

\section{TABLE V}

SPUTUM SPECIMENS YIELDING PREDOMINANT GROWTH OF KLEBSIELLA SHOWING PRESENCE OF A PREVIOUS PATHOGEN

\begin{tabular}{lccc} 
Species Isolated & $\begin{array}{l}\text { Previous } \\
\text { Pathogen } \\
\text { Isolated }\end{array}$ & $\begin{array}{l}\text { No Previous } \\
\text { Pathogen } \\
\text { Isolated }\end{array}$ & Total \\
\hline K. aerogenes & 18 & 17 & 35 \\
K.pneumoniae & - & 9 & 9 \\
Other Klebsiella spp. & - & 3 & 3
\end{tabular}

Klebsiella species occurred as the predominant growth in 65 of these, obtained from 47 patients, but of these only 25 strains from 12 patients were species other than $K$. aerogenes. By comparison $H$. influenzae was isolated from 356 sputa, pneumococci from 330, Staph. pyogenes from 180, and Ps. pyocyanea from 120 . A proportion of these specimens were also duplicates from one patient, but strains of $H$. influenzae and pneumococci, being very sensitive to treatment, mainly represent individual infections.

Table VI shows the antibiotic sensitivities of Klebsiella strains from sputum. It shows the total resistance of all strains to penicillin $G$ and the comparatively greater resistance to most antibiotics of $K$. aerogenes (Cabelli and Goldberg, 1955) particularly marked with ampicillin and tetracycline. Finally it demonstrates the rather surprisingly high percentage sensitivity in vitro of all types, and in particular the lung pathogens, to sulphonamides.

Table VII shows the results of mouse pathogenicity tests using the modification of Foster and Bragg's method. No mice were killed by any of our strains using the method described by Stokes (1960). 
TABLE VI

ANTIBIOTIC SENSITIVITIES OF KLEBSIELLA SPECIES ISOLATED FROM SPUTUM

\begin{tabular}{|c|c|c|c|c|c|c|c|c|c|}
\hline & \multirow{2}{*}{$\begin{array}{l}\text { No. of } \\
\text { Strains }\end{array}$} & \multicolumn{8}{|c|}{ Proportion of Strains Resistant to: } \\
\hline & & Penicillin & Ampicillin & $\begin{array}{l}\text { Strepto- } \\
\text { mycin }\end{array}$ & $\begin{array}{l}\text { Tetra- } \\
\text { cycline }\end{array}$ & $\begin{array}{l}\text { Chloram- } \\
\text { phenicol }\end{array}$ & $\begin{array}{l}\text { Poly- } \\
\text { myxin }\end{array}$ & $\begin{array}{l}\text { Kana- } \\
\text { mycin }\end{array}$ & $\begin{array}{l}\text { Sulphon- } \\
\text { amide }\end{array}$ \\
\hline $\begin{array}{l}K . \text { aerogenes, including Enterobacter } \\
K . \text { edwardsii ( } 2 \text { types) } \\
K . \text { pncumoniae } \\
K . \text { rhinoscleromatis } \text { and } K . \text { ozaenae }\end{array}$ & $\begin{array}{r}35 \\
7 \\
2 \\
3\end{array}$ & $\begin{array}{l}35(100 \%) \\
7(100 \%) \\
2(100 \%) \\
3(100 \%)\end{array}$ & $\begin{array}{l}31(89 \%) \\
2(29 \%) \\
1 \\
0\end{array}$ & $\begin{array}{l}12(34 \%) \\
1(14 \%) \\
0 \\
1\end{array}$ & $\begin{array}{l}30(86 \%) \\
2(29 \%) \\
0 \\
0\end{array}$ & $\begin{array}{l}8(23 \%) \\
1(14 \%) \\
0 \\
0\end{array}$ & $\begin{array}{l}0 \\
0 \\
0 \\
0\end{array}$ & $\begin{array}{l}1(3 \%) \\
1(14 \%) \\
0 \\
0\end{array}$ & $\begin{array}{l}11(31 \%) \\
1(14 \%) \\
0 \\
0\end{array}$ \\
\hline
\end{tabular}

\section{DISCUSSION}

The official definition of the Klebsiella group (Report, 1963) still fails to distinguish between $K$. aerogenes and $K$. pneumoniae and does not recognize the existence of $K$. edwardsii, an opinion having so far not been sought on Cowan's classification. Our results show that it is important to distinguish $K$. aerogenes in clinical work. Thirty-two

\section{TABLE VII}

MOUSE PATHOGENICITY OF KLEBSIELLA STRAINS ISOLATED FROM SPUTUM

$\begin{array}{lll}\text { Test } & \text { Test } & \text { No. of } \\ \text { Positive } & \text { Negative } & \text { Strains }\end{array}$ Positive Negative Strains

\begin{tabular}{llcc}
\hline K. aerogenes (including & 4 & 31 & 35 \\
$\begin{array}{l}\text { Enterobacter aerogenes) } \\
\text { pneumoniae (including }\end{array}$ & 5 & 4 & 9 \\
$\begin{array}{l}\text { K. edwardsii) } \\
\begin{array}{l}\text { Other Klebsiella spp. } \\
(\text { K. rhinoscleromatis } \text { and ozaenae) }\end{array}\end{array}$ & 1 & 2 & 3
\end{tabular}

of our $35 K$. aerogenes strains from sputum occurred after antibiotic therapy; in 18 an undoubted pathogen had previously been present, for which treatment was given. In 12 of these $18, K$. aerogenes was first isolated from specimens showing definite reduction in the degree of purulence as compared with those containing the original pathogen. Of the 17 patients yielding $K$. aerogenes but no previous pathogens, only two had frankly purulent sputum. One of these was a patient not known to be receiving antibiotics. Although $K$. aerogenes formed the predominant growth from two other patients not previously treated with antibiotics, it occurred in mucoid specimens and there were no signs of chest infection. By contrast the appearance of only three of 12 other Klebsiella species followed antibiotic treatment; in no case had there been a previous pathogen. Seven of nine specimens of sputum yielding either $K$. pneumoniae or $K$. edwardsii were grossly purulent. Thus the occurrence of $K$. aerogenes is almost invariably in the nature of secondary replacement of a previous pathogen, though its occasional role as a pathogen itself cannot be excluded. Other species are more often primary pathogens, though this is not invariably so, particularly with $K$. rhinoscleromatis and $K$. ozaenae.
Cowan's classification readily accommodates most hospital strains, but is too complex even in modified form for routine use for which it was not primarily intended. We used an extended series of tests to allow exact identification of strains, but a routine laboratory can identify Klebsiella species and distinguish $K$. aerogenes from other types using the IMViC reactions. Atypically reacting types, for instance indole-producing strains, occur particularly in sputum (Ørskov, 1955) but most strains would be correctly identified with the addition of only a citrate medium and glucose phosphate broth to the routine fermentation tests. A motility test gives added confirmation and distinguishes otherwise typical strains which are actively motile: these are probably better designated Enterobacter aerogenes (Hormaeche and Edwards, 1960) but in our experience of only a few strains these are of similar significance to $K$. aerogenes in specimens of sputum. There is, however, some difference in the sensitivity of E. aerogenes to the newer antibiotics, notably the cephalosporins, to which they, unlike Klebsiella strains, are resistant (Fleming, Goldner, and Glass, 1963). A test for $\mathrm{H}_{2} \mathrm{~S}$ production distinguishes citrobacter strains, the main group of citrateutilizing organisms which may cause confusion.

If Simmon's citrate is used all reactions, including methyl red and Voges-Proskauer, can be read and a report given late on the day after the isolation of the organism. This practice is not to be recommended for strict systematic work, but in clinical work is preferable to relying on colonial appearance alone. While Klebsiella species are typically mucoid, low, non-mucoid variants are common. Many other organisms form mucoid colonies on modified media (Anderson and Rogers, 1963) and using ordinary media we have encountered mucoid strains of $E$. coli (Milner, 1963) and of Pseudomonas pyocyanea. The latter particularly resemble the lung pathogens of the Klebsiella group, but are readily distinguished using Kovacs' test (Kovacs, 1956) and the medium of Hugh and Leifson (1953), simple procedures which deserve to be more extensively used in the routine laboratory. For routine purposes we would accept as Klebsiella species non-motile Gramnegative rods which fail to produce indole or $\mathrm{H}_{2} \mathrm{~S}$ but 
utilize citrate. The key tests for distinguishing $K$. aerogenes are the methyl red and VogesProskauer reactions (Foster and Bragg, 1962). This type almost invariably gives a negative methyl red and positive Voges-Proskauer reaction. When $K$. edwardsii-edwardsii gives this pattern (a result we have not encountered) its lack of gas production in glucose serves to distinguish the two, being in marked contrast to the usually vigorous gas production of $K$. aerogenes. The common pattern we have seen with $K$. edwardsii-ed. has been positive results with both tests (Table III). The mouse pathogenicity test stressed by Stokes (1960) as the most reliable means of differentiating $K$. aerogenes from Bact. friedlander $i$ has in our hands given some general indication of pathogenicity but has not been wholly reliable. Possibly strains from cases of pneumonia rather than bronchitis would have shown more clear-cut results, but we do not feel that in the average routine laboratory infrequently performed animal tests are satisfactory.

We would use the term $K$. aerogenes for clinical reports. It is sufficiently similar to the old terminology to be recognized by clinicians as an organism of similar clinical significance to $E$. coli, which is, we feel, a fair assessment of its role as a human pathogen. We cannot agree with Foster and Bragg that one group rather than another should bear the name $K$. pneumoniae, on the basis that it produces a severer type of chest infection. The indiscriminate use of that title for all types of Klebsiella, other than $K$. aerogenes, when they occur in sputum is not in the interests of rational nomenclature, while the term 'Klebsiella species' carries for the clinician the implication of an organism incompletely identified or of doubtful significance. We suggest the collective term 'Friedlander's bacillus' be used in clinical reports for Klebsiella species occurring as primary pathogens in the lung, namely, $K$. edwardsii-ed., $K$. pneumoniae and $K$. edwardsii-atlantae, and possibly $K$. rhinoscleromatis and $K$. ozaenae. It avoids the use of the word 'bacterium' and is recognized by clinicians as indicating a lung pathogen. It should not be used for all Klebsiella strains from sputum, for our results show that the majority, namely most of the strains of $K$. aerogenes, appear after antibiotic treatment of a previous infection. Such replacement of pathogens by coliform bacilli in the course of antibiotic therapy is known to occur (Thomas, Griffiths, and Huntsman, 1961). It has been called superinfection, but this is probably a misnomer. The process may only represent the colonization of the lungs by resistant organisms from the patient's own body flora. The source of such organisms is probably the bowel, yet $E$. coli was infrequently isolated in our series. A possible explanation is in the increasing use of broadspectrum antibiotics in the treatment of infections with $H$. influenzae. Ampicillin is now regarded by many as the drug of choice for this organism in the lung and has to some extent replaced tetracycline. Most $K$. aerogenes are resistant to the drug (Barber and Garrod, 1963) while many E. coli and Proteus mirabilis are sensitive. Ninety-two per cent of $K$. aerogenes isolated from sputa in this series were isolated following treatment with antibiotics, often given for another organism. Its occurrence, and for that matter the occurrence of $E$. coli, Citrobacter, or Proteus species in these circumstances probably does not constitute a progressive infection and attempts to eradicate them with broad-spectrum antibiotics may be unnecessary and result in their further replacement by such dangerous types as resistant staphylococci or Ps. pyocyanea.

We wish to thank Dr. Mary Barber and Dr. K. Patricia Carpenter for their advice and Dr. S. Cowan for permission to include Table I, adapted from his own table in the Journal of General Microbiology. Our thanks are also due to Dr. J. D. A. Gray, Central Middlesex Hospital, Dr. I. M. Ross, Ashford Hospital, and Dr. J. G. Selwyn, West Middlesex Hospital, who sent us strains, to Miss Janet Williams for technical assistance, and to Miss D. Crawford-Smith for the secretarial work involved.

\section{REFERENCES}

Anderson, E. S., and Rogers, A. H. (1963). Nature (Lond.), 198, 714. Barber, M. (1961). J. clin. Path., 14, 2.

Barber, M., and Garrod, L. P. (1963). Antibiotic and Chemotherapy, p. 81. Livingstone, Edinburgh and London.

Breed, R. S. (1948). In Bergey's Manual of Determinative Bacteriology, 6th ed. Balliere, Tindall and Cox, London.

Cabelli, V. J., and Goldberg, H. S. (1955). Antibiot. and Chemother., $5,386$.

Cowan, S. T. (1956). J. gen. Microbiol., 15, 345.

- Steel, K. J., Shaw, C., and Duguid, J. P. (1960). Ibid., 23, 601.

Finland, M., Jones, W. F. Jr., and Barnes, M. W. (1949). J. Amer. med. Ass., 170, 2188.

Fleming, P. C., Goldner, M., and Glass, D. G. (1963). Lancet, 1, 1399.

Foster, W. D., and Bragg, Jean (1962). J. clin. Path., 15, 478.

Hormaeche, E., and Edwards, P. R. (1958). Int. Bull. bact. Nomencl. $8,111$.

- —, - (1960). Ibid., 10, 71

Hugh, R., and Leifson, E. (1953). J. Bact., 66, 24.

Kauffmann, F. (1949). Acta path. microbiol. scand., 26, 381.
(1954). Enterobacteriaceae, 2nd ed. p. 223. Munksgaard, Copenhagen.

Kovacs, N. (1956). Nature (Lond.), 178, 703.

Maslen, L. G. C. (1952). Brit. med. J., 2, 545.

Milner, P. F. (1963). J. clin. Path., 16, 39.

Ørskov, I. (1955). Acta path. microbiol. scand., 37, 353.

Report (1954). Int. Bull. bact. Nomencl., 4, 141.

Report (1963). Ibid., 13, 69.

Shaw, C., and Clarke, P. H. (1955). J. gen. Microbiol., 13, 155.

Stokes, E. J. (1960). Clinical Bacteriology, 2nd ed., p. 114. Arnold, London.

Talbot, J. M., Cunliffe, A. C., and Gower, N. D. (1957). J. clin. Path., $10,222$.

Thomas, C. G. A., Griffiths, P. D., and Huntsman, R. G. (1961). Guy's Hosp. Rep., 110, 87.

Williams, R., Williams, E. D., and Hyams, D. E. (1960). Lancet, 1, 376. Yow, E. M. (1952). J. Amer. med. Ass., 149, 1184. 